\title{
EVALUATION OF GROUNDWATER QUALITY OF SIWA OASIS
}

Magdy.A.Wassel ${ }^{a}$, Ahmad. Z. Sayed ${ }^{a}$, Mostafa.M. Abo EL-Fadl ${ }^{b}$, and Ammar.M.Mahmod ${ }^{a}$

${ }^{a}$ Chemistry Department, Faculty of Science, Al-Azhar University, Nasr City, P.O. 11884, Cairo, Egypt

${ }^{b}$ Water Chemistry Department, Desert Research Center (DRC), Cairo, Egypt.

Corosponding auther: prof: Magdy. A. Wassel

E-mail ammarashour99@yahoo.com

\section{ABSTRACT}

Mobile no $+2001098380240,+2001116511495$

In this paper we discussed the water quality evaluation for use in different purposes, we will briefly examine some of the major important water quality standards. These standards serve as a basis for appraisal of the results of chemical water analysis in terms of suitability of the water for various intended uses. According to total dissolved salts (TDS), major ions as cations $\left(\mathrm{Ca}^{2+}, \mathrm{Mg}^{2+}, \mathrm{Na}^{+}, \mathrm{K}^{+}\right)$and anions $\left(\mathrm{CO}_{3}{ }^{2-}, \mathrm{HCO}_{3}^{-}, \mathrm{SO}_{4}{ }^{2-}, \mathrm{Cl}^{-}\right)$, with some heavy metals such as $\mathrm{Cd}^{2+}, \mathrm{Co}^{2+}$, $\mathrm{Cu}^{2+}, \mathrm{Mn}^{2+}, \mathrm{Mo}^{2+}, \mathrm{Ni}^{2+}, \mathrm{Pb}^{2+}, \mathrm{Sr}^{2+}, \mathrm{V}^{2+}, \mathrm{Zn}^{2+}, \mathrm{Al}^{3+}, \mathrm{B}^{3+}, \mathrm{Cr}^{3+}$ and $\mathrm{Fe}^{3+}$. The results indicate that the samples of Nubian sandstone aquifer is suitable for drinking of human and livestock, suitable for laundry purposes and for irrigation. While the samples of Fractured dolomite limestone aquifer are unsuitable for drinking and irrigation.

Keywords: Siwa Oesis, Evaluation, TDS, Heavy Metals.

\section{Council for Innovative Research}

Peer Review Research Publishing System

\section{Journal: Journal of Advances in Chemistry}

Vol.12, No. 4

www.cirworld.com, editor@cirworld.com 


\section{INTRODUCTION}

Siwa Oasis is a natural depression about $23 \mathrm{~m}$ below sea level. It covers an area of about $87.95 \mathrm{~km} 2$ are currently cultivated. The total numbers of inhabitants in Siwa were 21482 residents in 2006 [1]. The main activity in Siwa oasis is agriculture which depends on the groundwater that outflows from about 1199 wells and springs [2], giving a total annual discharge of about 255 million cubic meters. From this, about 222 million cubic meters are lost as evaporation and evapotranspiration, while the remainder goes to the natural lakes of Siwa Oasis [3].Thus, the annual surplus groundwaterbased on monitoring in 1997 and under present conditions reaches 33 million cubic meters [4].

This has led to a continuous rise in the water table level $(4.5 \mathrm{~cm} /$ year) causing water logging, soil salinization as a result of improper management and uncontrolled water flow from wells and springs and inefficiencies in the system of drainage water [5], and consequently deterioration in land productivity, which in turn results in lowering [6]. Agriculture income. Agriculture represents the basis of the Siwan economy International Union for Conservation of Nature (IUCN) [7].

The study focuses on investigating the economic impact of the environmental problem in the present and future; using the Autoregressive Integrated Moving Average models and geographic information systems that will lead to the quantitative assessment of desertification processes, its impact on agriculture to identify priorities for development beginning with areas of high development potential and less vulnerable to desertification processes [7].

The Environmental Problem in Siwa Oasis: The Siwa Oasis suffers many environmental problems such as; water logging; soil salinization; increase in the surface area of the saltwater lakes, Marshes and the rise of soil water levels by 4.5 $\mathrm{cm} /$ year. The results of these problems are deterioration in land productivity and which in turn results in lowering Agriculture income. Objectives: The research aims to identify the concept of quantitative measurement of desertification processes on agriculture production and income in the present and future, through the development of mathematical models, the Autoregressive Integrated Moving Average, with integration of Hydrochemical Information Systems and Remote Sensing that lead to the quantitative assessment of desertification processes in the present and future, as well as its impact on agriculture production and income to identify. The primary goal is to be achieved through the following subgoals:

Dealing with the space images, topographic maps and other available data to determine the environmental characteristics of Siwa Oasis. Monitoring the present and future desertification phenomena in Siwa Oasis, it's impact on resources, land use and development plans. Building integrated geographical information systems model of enviro- nmental and economical to identify the impact of desertification on the productivity and income on present and future [7].

\section{EXPERIMENTAL}

Water samples were collected from 24 different locations that cover the Siwa Oasis water resources through September 2014. After sampling, water samples carried out chemical analyses to assess the water quality. These samples were analyzed at the water and soil Lab unit in Desert Research Center fulfill the requirement suggested by the United States Geological Survey, and methods determining the inorganic substances in water and fluvial sediments. The concentrations of these constituents are expressed in milligrams per liter ( $\mathrm{mg} / \mathrm{l}, \mathrm{ppm})$, milli equivalents per liter (me/l) and percentage (\%). The analysis include the determination of the different properties of water such as TDS (Total Dissolved Salts), Major ions as $\mathrm{Na}^{+}, \mathrm{K}^{+}, \mathrm{Ca}^{2+}, \mathrm{Mg}^{2+}, \mathrm{CO}_{3}{ }^{2-}, \mathrm{SO}_{4}{ }^{2-}, \mathrm{HCO}_{3}{ }^{-}$and $\mathrm{Cl}^{-}[8]$.

\section{RESULTS AND DISCUSSION}

\subsection{Evaluation Of Groundwater Quality For Human Drinking, Laundry And Domestic Uses.}

The suitability of particular water for drinking, domestic, laundry and irrigation is controlled by many factors. Water used in human drinking and domestic purposes, for example, should be free of undesirable physical properties such as color or turbidity and should have pleasant taste and odor. Harmful micro-organisms should be virtually absent together with no excessive amount of dissolved elements. Moreover, for using water in laundry purposes, it should be soft or moderately hard. Water required for consumption of livestock and poultry is subjected to quality limitations nearly of the same type as those related to the quality of drinking water for human consumption, Table (1).

Table 1: Water quality guidelines for human drinking and domestic uses.

\begin{tabular}{|c|c|c||}
\hline $\begin{array}{c}\text { Chemical constituent or } \\
\text { Parameter }\end{array}$ & $\begin{array}{c}\text { Egyptian }{ }^{1} \text { maximum } \\
\text { Permissible limit in } \mathbf{~ g / l ~}\end{array}$ & $\begin{array}{c}\text { World }{ }^{2} \text { Health Organization } \\
\text { guidelines, 2008 } \\
\text { mg/l }\end{array}$ \\
\hline \hline TDS & 1000 & 1000 \\
\hline \hline Aluminum & 0.2 & - \\
\hline \hline Iron (total) & 0.3 & 0.01 \\
\hline \hline Lead & 1 & 3 \\
\hline \hline Zinc & 5 & 2 \\
\hline \hline Copper & 1 & \\
\hline
\end{tabular}




\begin{tabular}{|c||c||c|}
\hline Chromium & 0.01 & 0.05 \\
\hline \hline Cadmium & 0.003 & 0.003 \\
\hline \hline Manganese & - & 0.4 \\
\hline \hline Molypdinum & - & 0.07 \\
\hline \hline Strantium & - & 7 \\
\hline \hline Nickel & - & 0.07 \\
\hline \hline Boron & - & 0.5 \\
\hline \hline Fluoride & 5 & 1.5 \\
\hline \hline Cobalt & - & - \\
\hline \hline Vanadium & - & - \\
\hline
\end{tabular}

1- Egyptian standards for drinking and domestic uses (Higher committee for water, 2007), [9].

2-Guidelines for drinking water quality, $2^{\text {nd }}$ ed. Vol.2 Health criteria and other supporting information, World Health Organization, 2008, [10].

\subsubsection{Evaluation Of Groundwater Quality For Human Drinking according to:}

\subsection{1. a.Total Dissolves Salts:}

Making use of the aforementioned chemical data and standards for groundwater evaluation in the study area, the following can be deduced:

According to these standards, all samples of fractured dolomite and limestone aquifer (brackish and saline water samples) are unsuitable for human drinking while the samples of Nubian sandstone aquifer (fresh water) are excellent for drinking, Table (2).

Table 2 Evaluation of groundwater for human drinking according to salinity (TDS $\mathrm{mg} / \mathrm{l}$ )

\begin{tabular}{|l|c|c|c|c|}
\hline \multicolumn{1}{|c|}{ Aquifer } & $\begin{array}{c}\text { T.D.S } \\
<\mathbf{5 0 0} \mathbf{~ m g / l}\end{array}$ & $\begin{array}{c}\text { T.D.S } \\
\mathbf{5 0 0 - 1 0 0 0}\end{array}$ & $\begin{array}{c}\text { T.D.S } \\
\mathbf{1 0 0 0}-\mathbf{1 5 0 0}\end{array}$ & $\begin{array}{c}\text { T.D.S } \\
>\mathbf{1 5 0 0}\end{array}$ \\
\cline { 2 - 5 } & Excellent & Acceptable & Permissible & Unsuitable \\
\hline Nubian sandstone aquifer & $100 \%$ & - & - & - \\
\hline $\begin{array}{l}\text { Fractured dolomite and } \\
\text { limestone aquifer }\end{array}$ & - & - & - & $100 \%$ \\
\hline
\end{tabular}

\subsection{1.b. Inorganic Pollutants}

The pollution of groundwater samples is discussed through the measurements of trace elements, heavy metals and minor ions, including; $\mathrm{Al}^{3+}, \mathrm{B}^{3+}, \mathrm{Cd}^{2+}, \mathrm{Co}^{2+}, \mathrm{Cr}^{3+}, \mathrm{Cu}^{2+}, \mathrm{Fe}^{3+}, \mathrm{Mn}^{2+}, \mathrm{Mo}^{2+}, \mathrm{Ni}^{2+}, \mathrm{Pb}^{2+}, \mathrm{Sr}^{2+}, \mathrm{V}^{2+}$ and $\mathrm{Zn}^{2+}$ as shown in $\mathrm{Table}^{2}$ $6)$.

\subsection{1.c. Soluble heavy metals contents}

Based on the results of determined trace elements, heavy metals, minor ions and acceptable contaminant levels for drinking, it is clear that:

(1-) The ions concentration of $\mathrm{Al}^{3+}, \mathrm{B}^{3+}, \mathrm{Cd}^{2+}, \mathrm{Co}^{2+}, \mathrm{Cr}^{3+}, \mathrm{Cu}^{2+}, \mathrm{Fe}^{3+}, \mathrm{Mn}^{2+}, \mathrm{Mo}^{2+}, \mathrm{Ni}^{2+}, \mathrm{Pb}^{2+}, \mathrm{Sr}^{2+}, \mathrm{V}^{2+}$ and $\mathrm{Zn}^{2+}$, in all the studied sgroundwater samples are below the acceptable levels of contamination , $(0.2,0.5,0.003, \quad, 0.01,1,0.3,0.4$, 0.07, 0.07, 0.01, 7, , 3 (Higher committee for water, 2008 ), [10] respectively).

\subsection{1.c.i. Nubian sandstone aquifer}

The comparison between the maximum permissible limits of minor and trace for human drinking, Table (1) with the concentrations of these constituents in groundwater of the study area, leads to the following conclusions:

The concentrations of Aluminium, Boron, Cadmium, Cobalt, Cromium, Copper, Molybdinum, Nickel, Vanadium and Zinc are less than the detection limits of measurement by ICP instrument therefore these metals in the aquifer are drinkable, The metals of have positive values discussed as the following: 
a) The investigated groundwater samples of Nubian sandstone aquifer have iron $\left(\mathrm{Fe}^{3+}\right)$ content that ranges from less than 0.003 to $0.9 \mathrm{mg} / \mathrm{l}$, Table (3) and Fig.(1). About $60 \%$ of the investigated samples have iron content greater than the maximum permissible limit $(0.3 \mathrm{mg} / \mathrm{l})$, so they are polluted and not suitable for human drinking. It is worthy to mention that, most of the investigated samples, which are polluted with other trace elements, are polluted with iron. This means that, iron is the main contaminant among these trace elements. Such high content of iron can be attributed to the dissolution of iron bearing minerals commonly found in the catchment area and aquifer matrices.

b) The values of manganese $\left(\mathbf{M n}^{2+}\right)$ in the groundwater of Nubian sandstone aquifer ranges from 0.05 to $0.09 \mathrm{mg} / \mathrm{l}$, Table (4) and Fig.(2), in the limits of guidelines of WHO. This indicates that all groundwater samples are not contaminated by manganese and are therefore suitable for human drinking.

c) The content of $\mathbf{l e a d}\left(\mathbf{P b}^{2+}\right)$ in the groundwater of Nubian sandstone aquifer ranges from less than 0.005 to 0.0059 which is less than the maximum permissible limit $(0.01 \mathrm{mg} / \mathrm{l})$. This indicates that all groundwater samples of Nubian sandstone aquifer are not contaminated by lead and are therefore suitable for human drinking, Table (4) and Fig.(3).

d) The content of Strontium $\left(\mathrm{Sr}^{2+}\right)$ in the groundwater of Nubian sandstone aquifer ranges from less than 0.08 to 0.14 which is less than the maximum permissible limit $(7 \mathrm{mg} / \mathrm{l})$. This indicates that all groundwater samples of Nubian sandstone aquifer are not contaminated by Strontium and are therefore suitable for human drinking, Table (4) and Fig.(4).

Table 3: Soluble heavy metals and minor and trace constituents of Nubian sandstone aquifer (fresh water samples), (mg/l)

\begin{tabular}{|c|c|c|c|c|c|c|c|}
\hline $\begin{array}{c}\text { Sample } \\
\text { No. }\end{array}$ & $\mathrm{Al}^{3+}$ & $\mathrm{B}^{3+}$ & $\mathrm{Cd}^{3+}$ & $\mathrm{Co}^{2+}$ & $\mathrm{Cr}^{3+}$ & $\mathrm{Cu}^{2+}$ & $\mathrm{Fe}^{3+}$ \\
\hline 2 & $<0.03$ & $<<0.07$ & $<0.0005$ & $<0.001$ & $<0.01$ & $<0.006$ & $<0.03$ \\
\hline 3 & $<0.03$ & $<<0.07$ & $<0.0005$ & $<0.001$ & $<0.01$ & $<0.006$ & $<<0.03$ \\
\hline 9 & $<<0.03$ & $<<0.07$ & $<<0.0005$ & $<0.001$ & $<0.01$ & $<0.006$ & 0.9128 \\
\hline 10 & $<0.03$ & $<<0.07$ & $<<0.0005$ & $<0.001$ & $<0.01$ & $<0.006$ & 0.8062 \\
\hline$\overline{13}$ & $<<0.03$ & $<<0.07$ & $<0.0005$ & $<0.001$ & $<0.01$ & $<0.006$ & 0.6811 \\
\hline
\end{tabular}

Table 4: Soluble heavy metals and minor and trace constituents of Nubian sandstone aquifer (fresh water samples), (mg/l).

\begin{tabular}{|c||c|c|c||c|c|c|c||}
\hline $\begin{array}{c}\text { Sample } \\
\text { No. }\end{array}$ & $\mathbf{M n}^{2+}$ & $\mathbf{M o}^{2+}$ & $\mathrm{Ni}^{2+}$ & $\mathbf{P b}^{2+}$ & $\mathrm{Sr}^{2+}$ & $\mathrm{V}^{2+}$ & $\mathrm{Zn}^{2+}$ \\
\hline \hline $\mathbf{2}$ & 0.0552 & $<0.005$ & $<0.003$ & $<0.005$ & 0.1257 & $<0.009$ & $<0.001$ \\
\hline \hline $\mathbf{3}$ & 0.0565 & $<0.005$ & $<0.003$ & $<0.005$ & 0.1083 & $<0.009$ & $<0.001$ \\
\hline \hline $\mathbf{9}$ & 0.097 & $<0.005$ & $<0.003$ & $<0.005$ & 0.1423 & $<0.009$ & $<0.001$ \\
\hline \hline $\mathbf{1 0}$ & 0.0936 & $<0.005$ & $<0.003$ & $<0.005$ & 0.0945 & $<0.009$ & $<0.001$ \\
\hline \hline $\mathbf{1 3}$ & 0.0835 & $<0.005$ & $<0.003$ & 0.0059 & 0.08 & $<0.009$ & $<0.001$ \\
\hline
\end{tabular}

Note: Concentrations of $\mathrm{Al}^{3+}, \mathrm{B}^{3+}, \mathrm{Cd}^{2+}, \mathrm{Co}^{2+}, \mathrm{Cr}^{3+}, \mathrm{Cu}^{2+}, \mathrm{Mo}^{2+}, \mathrm{Ni}^{2+}, \mathrm{V}^{2+}$ and $\mathrm{Zn}^{2+}$ are less than the detection limits of measurement by ICP instrument. 


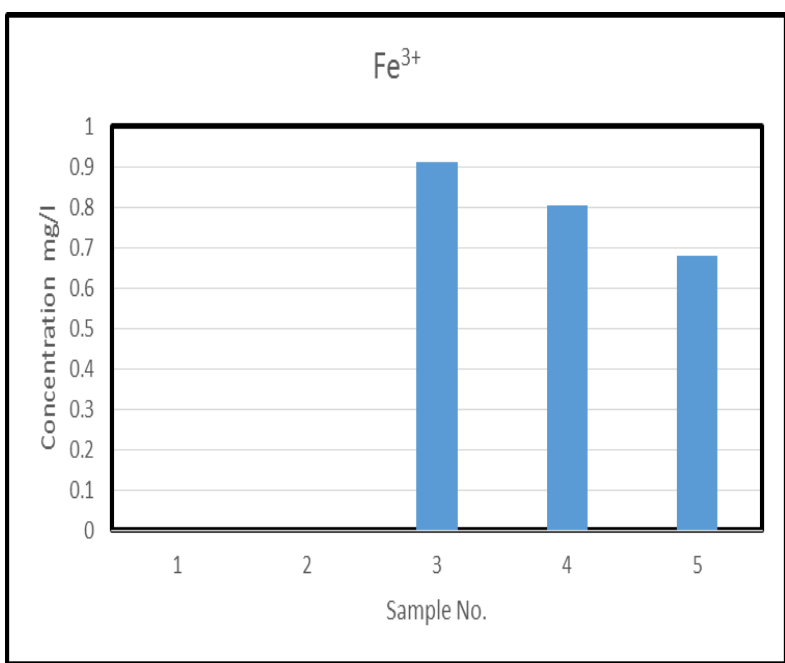

Fig(1) concentration of iron ion of Nubian sandstone aquifer.

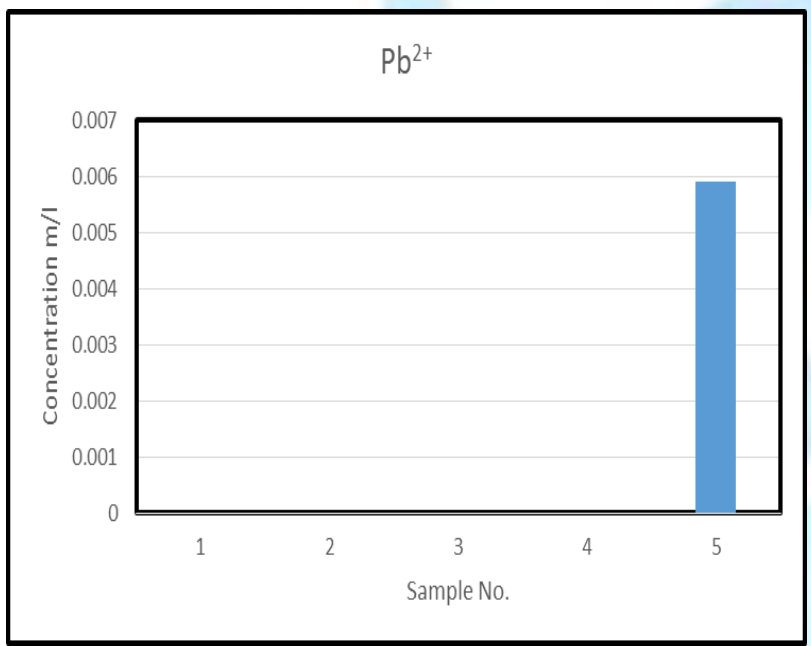

Fig(3) concentration of lead ion of Nubian sandstone aquifer.

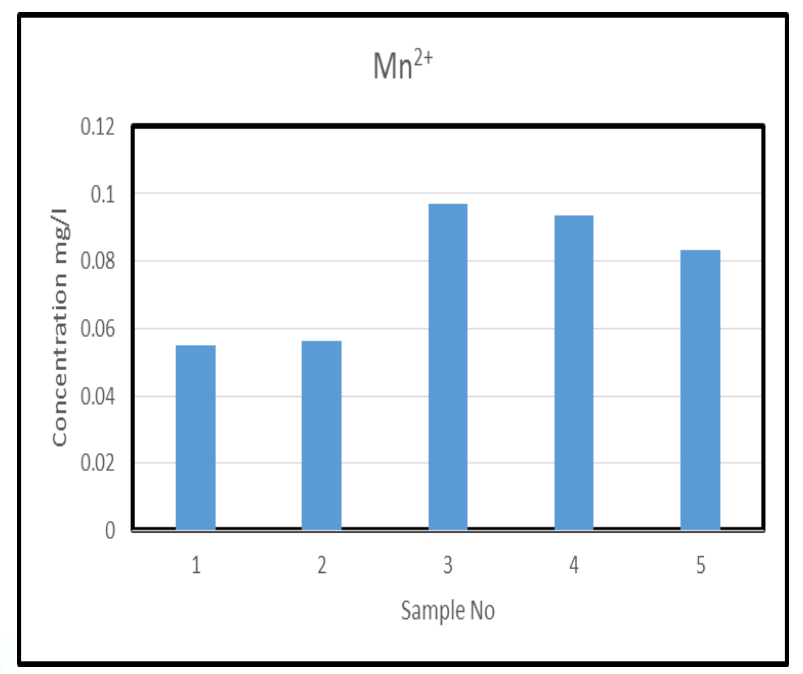

Fig(2) concentration of manganese ion of Nubian sandstone aquifer.

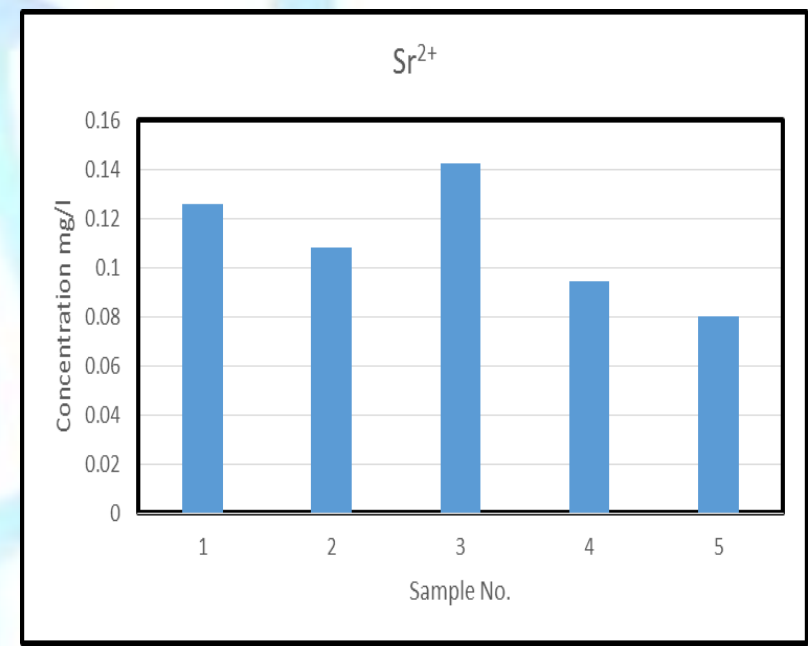

Fig(4) concentration of strontium ion of Nubian sandstone aquifer.

\subsection{1. c. ii Fractured dolomite and limestone aquifer}

The comparison between the maximum permissible limits of minor and trace for human drinking, Table (1) with the concentrations of these constituents in groundwater of the study area, leads to the following conclusions:

The concentrations of Aluminium, Cadmium, Cobalt, Cromium, Copper, Molybdinum and Nickel are less than the detection limits of measurement by ICP instrument therefore these metals in the aquifer are drinkable, The metals of have positive values discussed as the following:

a) The investigated groundwater samples have iron $\left(\mathrm{Fe}^{3+}\right)$ content that ranges from less than 0.003 to $8.76 \mathrm{mg} / \mathrm{l}$, Table (5) and Fig (5). About 32\% of the investigated samples have iron content greater than the maximum permissible limit $(0.3 \mathrm{mg} / \mathrm{l})$, so they are polluted and not suitable for human drinking. It is worthy to mention that, most of the investigated samples, which are polluted with other trace elements, are polluted with iron. This means that, iron is the main contaminant among these trace elements. Such high content of iron can be attributed to the dissolution of iron bearing minerals commonly found in the catchment area and aquifer matrices.

b) The content of manganese $\left(\mathrm{Mn}^{2+}\right)$ in the groundwater of aquifer ranges from less than 0.002 to $0.23 \mathrm{mg} / \mathrm{l}$, Table (6) and Fig (6). All the groundwater samples collected from Siwa Oasis have manganese content less than the permissible limit $(0.4 \mathrm{mg} / \mathrm{l})$. This indicates that all groundwater samples are not contaminated by manganese and are therefore suitable for human drinking. 
c) The content of lead $\left(\mathrm{Pb}^{2+}\right)$ in the groundwater samples of fractured dolomite and limestone aquifer is less than 0.007 which is less than the maximum permissible limit $(0.01 \mathrm{mg} / \mathrm{l})$. This indicates that all groundwater are not contaminated by lead and are therefore suitable for human drinking. Exceptional case is one sample has value $7.81 \mathrm{mg} / \mathrm{l}$ of lead which is greater than maximum permissible limit $(0.01 \mathrm{mg} / \mathrm{l})$. So this sample is polluted and not suitable for human drinking, Table (6) and Fig (7).

d) The content of $\boldsymbol{z i n c}\left(\mathrm{Zn}^{2+}\right)$ in the groundwater samples aquifer are ranges from less than 0.001 , to $0.86 \mathrm{mg} / \mathrm{l}$. The recommended value for zinc content in the groundwater is $3 \mathrm{mg} / \mathrm{l}$. So all the groundwater samples are suitable for drinking due to the values are less than the maximum permissible limits, Table (6) and Fig (8).

e) The contamination of the groundwater in the study area by Strontium $\left(\mathbf{S r}^{2+}\right)$ content ranges from less than 3.35 to $8.85 \mathrm{mg} / \mathrm{l}$, Table (6) and Fig (9). About $32 \%$ of the groundwater samples collected from this aquifer have Strontium content greater than the maximum permissible limit $(7 \mathrm{mg} / \mathrm{l})$. The high Strontium content is due to the common occurrence of Strontium in dolomitic and calcareous deposits encountered in the aquifer matrices.

f) The contamination of the groundwater in the study area by Boron $\left(\mathbf{B}^{3+}\right)$ content ranges from less than 0.27 to $1.42 \mathrm{mg} / \mathrm{l}$, Table (6) and Fig (10). About $63 \%$ of the groundwater samples collected from fractured dolomite and limestone aquifer have Boron content greater than the maximum permissible limit $(0.5 \mathrm{mg} / \mathrm{l})$. The high Boron content is due to the common occurrence of Boron in dolomitic and calcareous deposits encountered in the aquifer matrices.

g) The contamination of the groundwater in the study area by Vanadium $\left(\mathbf{V}^{2+}\right)$ content of Siwa Oasis water samples ranges from less than 0.009 to $0.012 \mathrm{mg} / \mathrm{l}$, Table (6) and Fig (11). So all the groundwater samples are suitable for drinking due to there is no guidelines for Vanadium ions in water.

Table (5): Soluble heavy metals and minor and trace constituents of Fractured dolomite and limestone aquifer (brackish and saline water samples), (mg/l).

\begin{tabular}{|c|c|c|c|c|c|c|c|}
\hline $\begin{array}{c}\text { Sample } \\
\text { No. }\end{array}$ & $\mathrm{Al}^{3+}$ & $\mathrm{B}^{3+}$ & $\mathrm{Cd}^{3+}$ & $\mathrm{Co}^{2+}$ & $\mathrm{Cr}^{3+}$ & $\mathrm{Cu}^{2+}$ & $\mathrm{Fe}^{3+}$ \\
\hline$\overline{11}$ & $2<0.03$ & 0.4266 & "<0.0005 & $<00.001$ & $<<0.01$ & $<0.006$ & 3.385 \\
\hline 4 & $<0.03$ & 0.6098 & $<0.0005$ & $<<0.001$ & $<<0.01$ & $<0.006$ & 0.3224 \\
\hline$\overline{5}$ & $2<0.03$ & $\begin{array}{l}.417 \\
\end{array}$ & "<0.0005 & $<00.001$ & $<<<0.01$ & $<0.006$ & 8.755 \\
\hline 6 & $<<0.03$ & 0.7256 & $<<0.0005$ & $<<0.001$ & $<<0.01$ & $<<0.006$ & 0.8258 \\
\hline$\overline{77}$ & $<0.03$ & 0.7478 & $<<0.0005$ & $<<0.001$ & $<0.01$ & $<0.006$ & 0.0633 \\
\hline$\overline{88}$ & $<<0.03$ & 0.5983 & $<<<0.0005$ & $<<0.001$ & $2<0.01$ & $<<0.006$ & 0.2244 \\
\hline 11 & $<0.03$ & 0.4111 & $<<0.0005$ & $<0.001$ & $<0.01$ & $<0.006$ & 0.3523 \\
\hline$\overline{12}$ & $<<0.03$ & 0.4404 & $<<<0.0005$ & $<<0.001$ & $2<0.01$ & $<<0.006$ & 0.197 \\
\hline 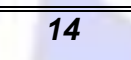 & $<<0.03$ & 0.8627 & $<0.0005$ & $<0.001$ & $<<0.01$ & $<0.006$ & 0.0421 \\
\hline$\overline{15}$ & $<0.03$ & 0.8432 & $<0.0005$ & $<0.001$ & $<<0.01$ & $<0.006$ & $<0.03$ \\
\hline 16 & $<0.03$ & 0.8543 & $<0.0005$ & $<0.001$ & $<0.01$ & $<0.006$ & $<0.03$ \\
\hline 17 & $<0.03$ & 0.7222 & $<0.0005$ & $<0.001$ & $<0.01$ & $<0.006$ & $<0.03$ \\
\hline$\overline{18}$ & $<0.03$ & 0.735 & $<0.0005$ & $<0.001$ & $<<0.01$ & $<0.006$ & $<<0.03$ \\
\hline 19 & $<0.03$ & 0.6463 & $<0.0005$ & $<0.001$ & $<0.01$ & $<0.006$ & 1.974 \\
\hline 20 & $<<0.03$ & 0.4377 & $<0.0005$ & $<0.001$ & $<<0.01$ & $<0.006$ & $<0.03$ \\
\hline 21 & $<<0.03$ & 0.3773 & $<<0.0005$ & $<00.001$ & $<<0.01$ & $<00.006$ & $<<0.03$ \\
\hline 22 & $<0.03$ & 0.2681 & $<0.0005$ & $<0.001$ & $<<0.01$ & $<0.006$ & $<<0.03$ \\
\hline 23 & $<0.03$ & 0.5837 & $<0.0005$ & $<0.001$ & $<0.01$ & $<0.006$ & $<0.03$ \\
\hline 24 & $<0.03$ & 0.3387 & $<0.0005$ & 0.09 & $<0.01$ & $<0.006$ & 0.0431 \\
\hline
\end{tabular}


Table (6): Soluble heavy metals and minor and trace constituents of Fractured dolomite and limestone aquifer (brackish and saline water samples), (mg/l).

\begin{tabular}{|c|c|c|c|c|c|c|c|}
\hline $\begin{array}{c}\text { Sample } \\
\text { No. }\end{array}$ & $\mathrm{Mn}^{2+}$ & $\mathrm{Mo}^{2+}$ & $\mathrm{Ni}^{2+}$ & $\mathrm{Pb}^{2+}$ & $\mathrm{Sr}^{2+}$ & $v^{2+}$ & $\mathrm{Zn}^{2+}$ \\
\hline$\overline{1} 1$ & 0.1148 & $<<0.005$ & $<0.003$ & 7.813 & 4.012 & $<0.009$ & 0.0029 \\
\hline 4 & 0.0211 & $<<0.005$ & $<<0.003$ & $<<0.005$ & 4.087 & $<<0.009$ & $<0.001$ \\
\hline 5 & 0.2293 & $<<0.005$ & $<0.003$ & $<<0.005$ & 8.389 & $<0.009$ & $<0.001$ \\
\hline 6 & 0.0366 & $<0.005$ & $<0.003$ & 0.0065 & 7.771 & $<0.009$ & $<0.001$ \\
\hline 7 & 0.0556 & $<0.005$ & $<0.003$ & $<0.005$ & 5.972 & $<0.009$ & $<0.001$ \\
\hline 8 & 0.0925 & $<0.005$ & $<0.003$ & $<0.005$ & 25.453 & $<0.009$ & 0.0056 \\
\hline$\overline{11}$ & 0.0055 & $<<0.005$ & $<0.003$ & $<0.005$ & 4.027 & $<0.009$ & $<0.001$ \\
\hline 12 & 0.0288 & $<0.005$ & $<0.003$ & $<0.005$ & 4.607 & $<0.009$ & $<0.001$ \\
\hline$\overline{14}$ & $<<<0.002$ & $<0.005$ & $<<0.003$ & $<0.005$ & 8.693 & $<0.009$ & 0.8627 \\
\hline 15 & $<0.002$ & $<0.005$ & $<0.003$ & $<0.005$ & 8.464 & $<0.009$ & 0.8432 \\
\hline 16 & 0.0006 & $<0.005$ & $<<0.003$ & $<0.005$ & 8.851 & 0.0105 & 0.8543 \\
\hline 17 & $<0.002$ & $<0.005$ & $<0.003$ & $<0.005$ & 8.327 & $<0.009$ & 0.7222 \\
\hline 18 & 0.0254 & $<0.005$ & $<0.003$ & $<0.005$ & 6.471 & 0.0104 & 0.735 \\
\hline 19 & 0.0921 & $<0.005$ & $<0.003$ & $<0.005$ & 5.138 & 0.012 & 0.6463 \\
\hline 20 & 0.0122 & $<0.005$ & $<0.003$ & $<0.005$ & 4.184 & $<0.009$ & $<0.001$ \\
\hline 21 & 0.0133 & $<0.005$ & $<0.003$ & $<0.005$ & 3.642 & $<0.009$ & $<0.001$ \\
\hline 22 & $<<0.002$ & $<0.005$ & $<0.003$ & $<0.005$ & 3.348 & $<0.009$ & $<0.001$ \\
\hline 23 & 0.0807 & $<0.005$ & $<0.003$ & $<0.005$ & 5.393 & $<0.009$ & $<0.001$ \\
\hline 24 & 0.012 & $<<0.005$ & $<<0.003$ & $<<0.005$ & 3.949 & $<<0.009$ & $<<0.001$ \\
\hline
\end{tabular}

Note: Concentrations of $\mathrm{Al}^{3+}, \mathrm{Cd}^{2+}, \mathrm{Co}^{2+}, \mathrm{Cr}^{3+}, \mathrm{Cu}^{2+}, \mathrm{Mo}^{2+}$ and $\mathrm{Ni}^{2+}$, are less than the detection limits of measurement by ICP instrument.

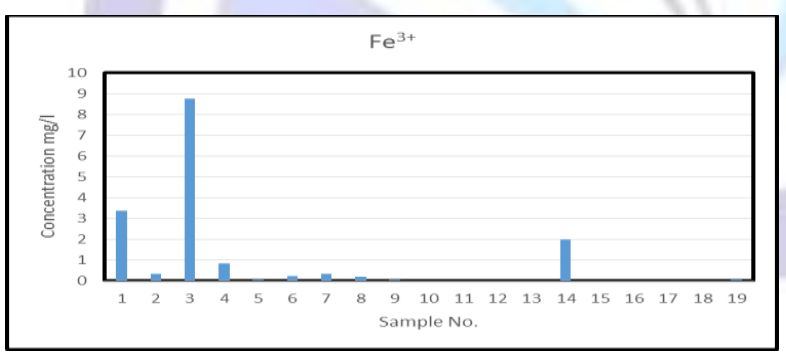

Fig(5) concentration of iron ion of fractured dolomite limestone aquifer.

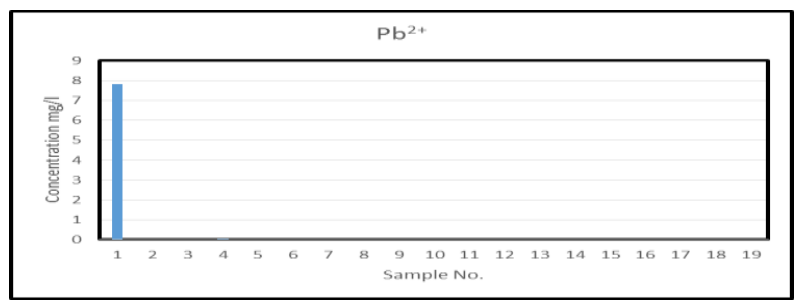

Fig(7) concentration of lead ion of fractured dolomite limestone aquifer.

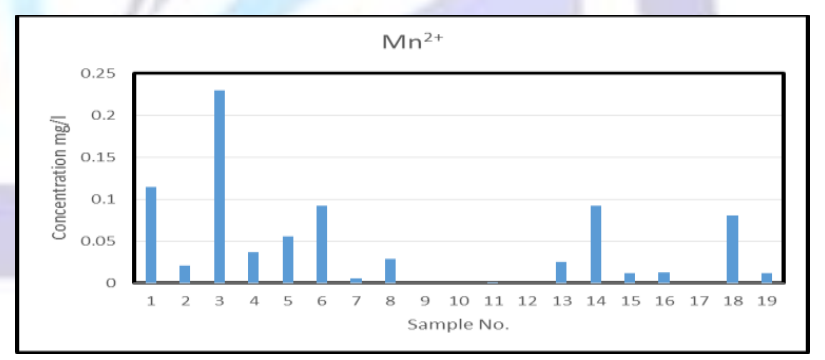

Fig(6) concentration of manganese ion of fractured dolomite limestone aquifer.

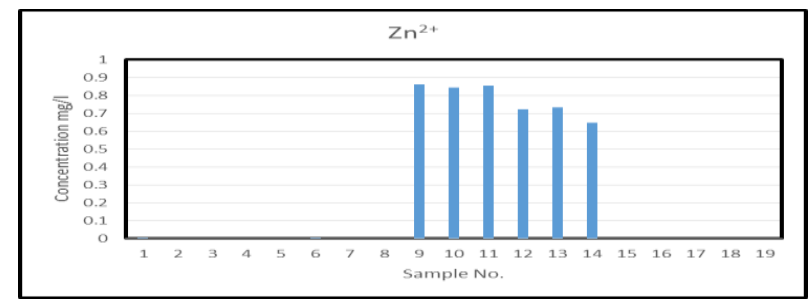

Fig(8) concentration of zinc ion of fractured dolomite limestone aquifer. 


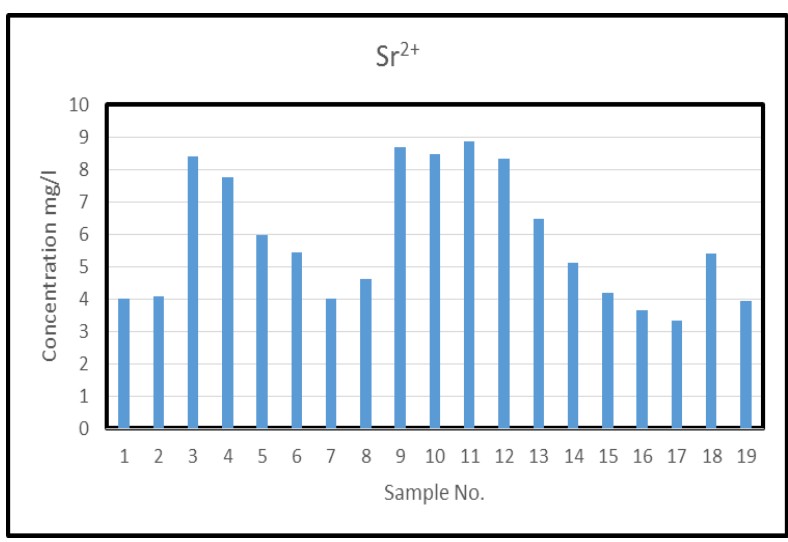

Fig(9) concentration of strontium ion of fractured dolomite limestone aquifer.

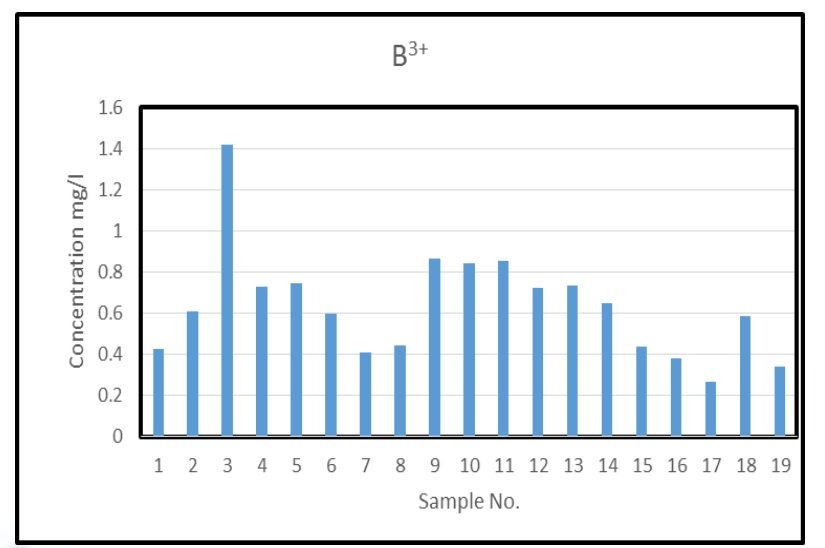

Fig(10) concentration of boron ion of fractured dolomite limestone aquifer.

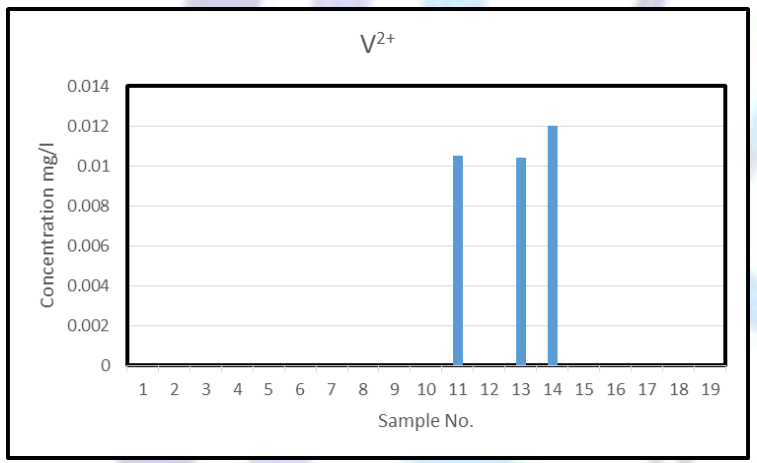

Fig (11) concentration of iron ion of fractured

dolomite limestone aquifer

\section{2. Evaluation of groundwater quality for domestic and laundry.}

Water is classified according to its total hardness as shown in Table (7) [11]. For water usage in domestic and laundry, its total hardness should be soft to moderately hard.

Table 7: Classification of water for laundry usage according to its total hardness, [11].

\begin{tabular}{|c||c||}
\hline Classification & $\begin{array}{c}\text { Total hardness } \\
\left(\mathrm{mg} / \mathrm{l} \text { as } \mathrm{CaCO}_{3}\right)\end{array}$ \\
\hline Soft & $0-17$ \\
\hline Slightly hard & $17.1-60$ \\
\hline Moderately hard & $61-120$ \\
\hline Hard & $121-180$ \\
\hline Very hard & $180 \&$ over \\
\hline
\end{tabular}


The samples of Nubian sandstone aquifer represented as $60 \%$ of samples are slightly hard and $40 \%$ of samples are moderately hard so the samples of Nubian sandstone aquifer are suitable for domestic and laundry. While all the groundwater samples of Fractured dolomite and limestone aquifer are unsuitable for laundry uses because they are very hard waters (total hardness $>180$ ), as shown in Table (8)

Table 8: Evaluation of groundwater samples of the different aquifers in the study area for laundry and domestic uses.

\begin{tabular}{||c||c|c||}
\hline \multirow{2}{*}{$\begin{array}{c}\text { Grade of } \\
\text { classification }\end{array}$} & \multicolumn{2}{c|}{$\begin{array}{c}\text { The percentages of the different aquifers groundwater in the } \\
\text { study area }\end{array}$} \\
\cline { 2 - 3 } & $\begin{array}{c}\text { Nubian sandstone aquifer } \\
\text { (fresh water) }\end{array}$ & $\begin{array}{c}\text { Fractured dolomite and } \\
\text { limestone aquifer (brackish } \\
\text { and saline water) }\end{array}$ \\
\hline \hline Soft & $0 \%$ & $0 \%$ \\
\hline Slightly hard & $60 \%$ & $0 \%$ \\
\hline Moderately hard & $40 \%$ & $0 \%$ \\
\hline Hard & $0 \%$ & $0 \%$ \\
\hline Very hard & $0 \%$ & $100 \%$ \\
\hline
\end{tabular}

\section{3. Evaluation of Groundwater Quality for Drinking of Livestock and Poultry.}

Water to be used by livestock is generally subjected to quality limitations like those of humans. However, livestock is generally able to consume waters of high mineral content than recommended for human consumption.

The classification of [12], Table (9) was used in the present study. Accordingly, the studied groundwater can be evaluated as follows:

3.3.1. Nubian sandstone aquifer; All samples are excellent for all livestock and poultry Table (10), where salinity is less than 1000 ppm.

Table 9: Guide to the use of saline waters for livestock and poultry, [12].

\begin{tabular}{|c|c|}
\hline Total soluble salts & Characters \\
\hline $\begin{array}{l}\text { (Less than } 1,000 \mathrm{mg} / \mathrm{l}) \\
\mathrm{EC}<1.5 \mathrm{mmhos} / \mathrm{cm}\end{array}$ & Relatively low level of salinity. Excellent for all classes of livestock and poultry. \\
\hline $\begin{array}{l}(1,000-3,000 \mathrm{mg} / \mathrm{l}) \\
E C=1.5-5 \mathrm{mmhos} / \mathrm{cm}\end{array}$ & $\begin{array}{l}\text { Very satisfactory for all classes of livestock and poultry. May cause temporary and } \\
\text { mild diarrhea in livestock not accustomed to them; may cause watery droppings in } \\
\text { poultry. }\end{array}$ \\
\hline $\begin{array}{l}(3,000-5,000 \mathrm{mg} / \mathrm{l}) \\
E C=5-8 \mathrm{mmhos} / \mathrm{cm}\end{array}$ & $\begin{array}{l}\text { Satisfactory for livestock but may cause temporary diarrhea or be refused at first } \\
\text { by animals not accustomed to them. Poor waters for poultry, often causing watery } \\
\text { feces, increased mortality, and decreased growth, especially in turkeys. }\end{array}$ \\
\hline $\begin{array}{l}(5,000-7,000 \mathrm{mg} / \mathrm{l}) \\
E C=8-11 \mathrm{mmhos} / \mathrm{cm}\end{array}$ & $\begin{array}{l}\text { Can be used with reasonable safety for dairy and beef cattle, sheep, swine, and } \\
\text { horses. Avoid use for pregnant or lactating animals. Not acceptable for poultry. }\end{array}$ \\
\hline $\begin{array}{l}(7,000-10,000 \mathrm{mg} / \mathrm{l}) \\
E C=11-16 \mathrm{mmhos} / \mathrm{cm}\end{array}$ & $\begin{array}{l}\text { Unfit for poultry and probably for swine .Considerable risk in using for pregnant or } \\
\text { lactating cows, horses or sheep, or for the young of these species. } \\
\text { In general, use should be avoided although older ruminants, horses, poultry, and } \\
\text { swine may subsist on them under certain conditions. }\end{array}$ \\
\hline $\begin{array}{l}\text { Over } 10,000 \mathrm{mg} / \mathrm{l} \\
\mathrm{EC}>16 \mathrm{mmhos} / \mathrm{cm}\end{array}$ & $\begin{array}{l}\text { Risks with these highly saline waters are so great that they cannot be } \\
\text { recommended for use under any condition. }\end{array}$ \\
\hline
\end{tabular}

3.3.2. Fractured dolomite and limestone aquifer; the great portion groundwater samples (42\%) are Very satisfactory for all classes of livestock and poultry. May cause temporary and mild diarrhea in livestock not accustomed to them; may cause watery droppings in poultry, since these waters have salinities in the range of 1000-3000 ppm. Also, about (26\%) of total samples Satisfactory for livestock but may cause temporary diarrhea or be refused at first by animals not accustomed to them. Poor waters for poultry, often causing watery feces, increased mortality, and decreased growth, especially in turkeys. Since water salinity ranges from 3000 to $5000 \mathrm{ppm}$. While (26\%) of the samples Can be used with reasonable safety for dairy and beef cattle, sheep, swine, and horses. Avoid use for pregnant or lactating animals. Not acceptable for poultry. Since water salinity ranges from 5000 to $7000 \mathrm{mg} / \mathrm{l}$. The rest of samples (6\%) 
Unfit for poultry and probably for swine .Considerable risk in using for pregnant or lactating cows, horses or sheep, or for the young of these species. In general, use should be avoided although older ruminants, horses, poultry, and swine may subsist on them under certain conditions. Since water salinity ranges from 7000 to $10000 \mathrm{mg} / \mathrm{l}$, Table (10).

In general, most of the groundwater samples in the study area (75\% of total samples) are suitable for drinking of livestock and poultry, since they have a total soluble salts less than $5000 \mathrm{mg} / \mathrm{l}$ while the rest $(25 \%$ of total samples) are unsuitable for this purpose. due to their high content of total dissolved solids (more than $5000 \mathrm{mg} / \mathrm{l}$ ), these groundwater samples tapping the marine deposits in the study area.

Table 10: Evaluation of groundwater samples in the study area for drinking of livestock and poultry.

\begin{tabular}{|c|c|c|c|}
\hline \multirow[b]{2}{*}{$\begin{array}{l}\text { Grade of } \\
\text { classification }\end{array}$} & \multirow[b]{2}{*}{$\begin{array}{c}\text { Total soluble } \\
\text { salts of water } \\
\text { used }\end{array}$} & \multicolumn{2}{|c|}{$\begin{array}{l}\text { The percentages of groundwater in the study } \\
\text { area }\end{array}$} \\
\hline & & $\begin{array}{c}\text { Nubian sandstone } \\
\text { aquifer } \\
\text { (fresh water) }\end{array}$ & $\begin{array}{c}\text { Fractured dolomite and } \\
\text { limestone aquifer } \\
\text { (brackish and } \\
\text { saline water) }\end{array}$ \\
\hline Excellent & $<1000 \mathrm{mg} / \mathrm{l}$ & $100 \%$ & - \\
\hline Very satisfactory & $\begin{array}{c}1000- \\
3000 \mathrm{mg} / \mathrm{l}\end{array}$ & & $42 \%$ \\
\hline satisfactory & $\begin{array}{c}3000- \\
5000 \mathrm{mg} / \mathrm{l}\end{array}$ & - & $26 \%$ \\
\hline Not acceptable & $\begin{array}{l}5000- \\
7000 \mathrm{mg} / \mathrm{l}\end{array}$ & - & $26 \%$ \\
\hline Unfit water & $\begin{array}{c}7000- \\
10000 \mathrm{mg} / \mathrm{l}\end{array}$ & - & $6 \%$ \\
\hline Not recommended & $>10000 \mathrm{mg} / \mathrm{l}$ & - & - \\
\hline
\end{tabular}

\subsection{Evaluation of Groundwater for Irrigation Purposes.}

The quality of water used for irrigation is well recognized as an important factor in the productivity of the crops. Concerning the quality of water for irrigation purposes, many different classifications have been proposed in an effort to anticipate, with reasonable certainty, the effect of particular irrigation water on soils and plants under ordinary conditions. In general, quality standards for irrigation water are based on the following: -

-The total concentration of soluble salts (TDS)

-The relative proportion of sodium to other cations.

-The bicarbonate concentration as related to the concentration of calcium and magnesium (Residual Sodium Carbonate, $\mathrm{RSC})$.

\subsubsection{Evaluation of Groundwater Quality for Irrigation According to the Effective Salinity Classification [13,14].}

The experiments carried out by [13] revealed that $\mathrm{EC}_{\mathrm{w}}$ is not a correct measure for salt accumulation in soil. This is due to the precipitation of calcium and magnesium carbonate (dolomite and calcite) at the highest concentrations of soil solution. Moreover, some soluble salts are precipitated in the gypsum form $\left(\mathrm{CaSO}_{4}\right)$. Therefore, the carbonates of calcium and magnesium as well as calcium sulfate should not be considered in evaluating the hazardous role of soil salinity. Other soluble salts in irrigation water are referred to as effective salinity, [13].

Therefore, effective salinity can be determined by supposing that the carbonates of $\mathrm{Ca}^{2+}$ and $\mathrm{Mg}^{2+}$ together with calcium sulfate are precipitated from water. Accordingly, the effective salinity in soil is composed of the salts of $\mathrm{NaCl}_{\text {and }} \mathrm{MgSO}_{4}$, i.e., the effective salinity can be determined by calculating the sum of chloride ion concentration plus half the concentration of sulfate ion in water (me/l) as follows:

Effective salinity $=\mathrm{Cl}^{-}+1 / 2 \mathrm{SO}_{4}{ }^{2-}(\mathrm{me} / \mathrm{l})$

Table (11) reveals the relative standards of effective irrigation water salinity according to Doneen 
Table 11: Relative standards of effective irrigation water salinity according to [14].

\begin{tabular}{|l||c|c|c||}
\hline \multicolumn{1}{|c||}{ Soil conditions } & \multicolumn{3}{c||}{ Grades of effective salinity as me/l } \\
\cline { 2 - 4 } & $\begin{array}{c}\text { Class } \\
\text { (I) }\end{array}$ & Class (II) & $>5$ \\
\hline \hline $\begin{array}{l}\text { Soil with low permeability, less leaching and } \\
\text { slow shallow drainage. }\end{array}$ & $<3$ & $3-5$ & $>10$ \\
\hline $\begin{array}{l}\text { Soil with moderate permeability, limited } \\
\text { leaching, slow and deep drainage. }\end{array}$ & $<5$ & $5-10$ & $>15$ \\
\hline $\begin{array}{l}\text { High permeable soil with deep and easy } \\
\text { drainage. }\end{array}$ & $<7$ & $7-15$ & $>5$ \\
\hline
\end{tabular}

Applying this classification, (table 11), for the groundwater collected from the study area, the following can be deduced

3.4.1. a. Nubian sandstone aquifer (fresh groundwater samples). All samples of Nubian sandstone aquifer can be classified as water of the first grade (class I), in case of soil with low permeability less leaching and slow shallow drainage, Table (12).

3.4.1. b. Fractured dolomite limestone aquifer (brackish and saline groundwater). All samples of fractured dolomite and limestone aquifer can be classified as water of the third grade (class III) of irrigation water High permeable soil with deep and easy drainage.

Table 12: Evaluation of the groundwater samples for irrigation according to the effective water salinity as me/l,

[14].

\begin{tabular}{|c|c|c|}
\hline \multirow[b]{2}{*}{ Soil conditions } & \multicolumn{2}{|c|}{ Aquifer type } \\
\hline & $\begin{array}{l}\text { Nubian sandstone } \\
\text { aquifer (fresh water) }\end{array}$ & $\begin{array}{c}\text { Fractured dolomite and limestone } \\
\text { aquifer (brackish and } \\
\text { saline water) }\end{array}$ \\
\hline \multicolumn{3}{|c|}{ Soil with low permeability, less leaching and slow shallow drainage. } \\
\hline Class (I) & $100 \%$ & - \\
\hline Class (II) & - & - \\
\hline Class (III) & - & - \\
\hline \multicolumn{3}{|c|}{ Soil with moderate permeability, limited leaching, slow and deep drainage. } \\
\hline Class (I) & - & - \\
\hline Class (II) & - & - \\
\hline Class (III) & 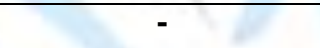 & - \\
\hline \multicolumn{3}{|c|}{ High permeable soil with deep and easy drainage. } \\
\hline Class (I) & - & - \\
\hline Class (II) & 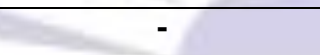 & 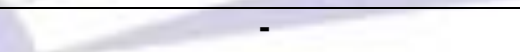 \\
\hline Class (III) & - & $100 \%$ \\
\hline
\end{tabular}

\subsubsection{Wilcox Classification [15].}

Wilcox [15] suggested the definition of sodium percentage relative to common cations as expressed in the following equation:

$$
\mathrm{Na} \%=\mathrm{Na}^{+} \times 100 / \mathrm{Ca}^{2+}+\mathrm{Mg}^{2+}+\mathrm{Na}^{+}
$$

This classification is based on the relationship between sodium percentage and total cations concentrations (where cations concentrations are in me/l), governing the suitability of waters for irrigation.

By applying this classification on the groundwater samples of the different aquifers in the study area, figure (12), one can conclude the following:

\subsection{2.a.Nubian sandstone aquifer}

From Table (13), it's obvious that, all samples are located in Excellent to good class for irrigation. 


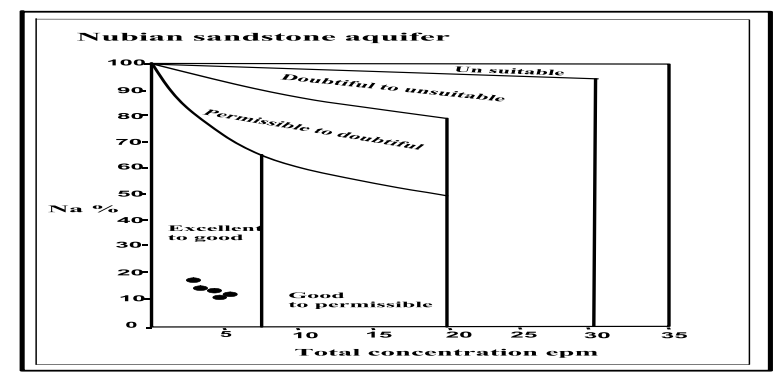

Fig. (12) Classification of the Nubian sandstone aquifer groundwater samples for irrigation purposes.

Table 13: Evaluation of water samples of the Nubian sandstone aquifer for irrigation according to Wilcox [15].

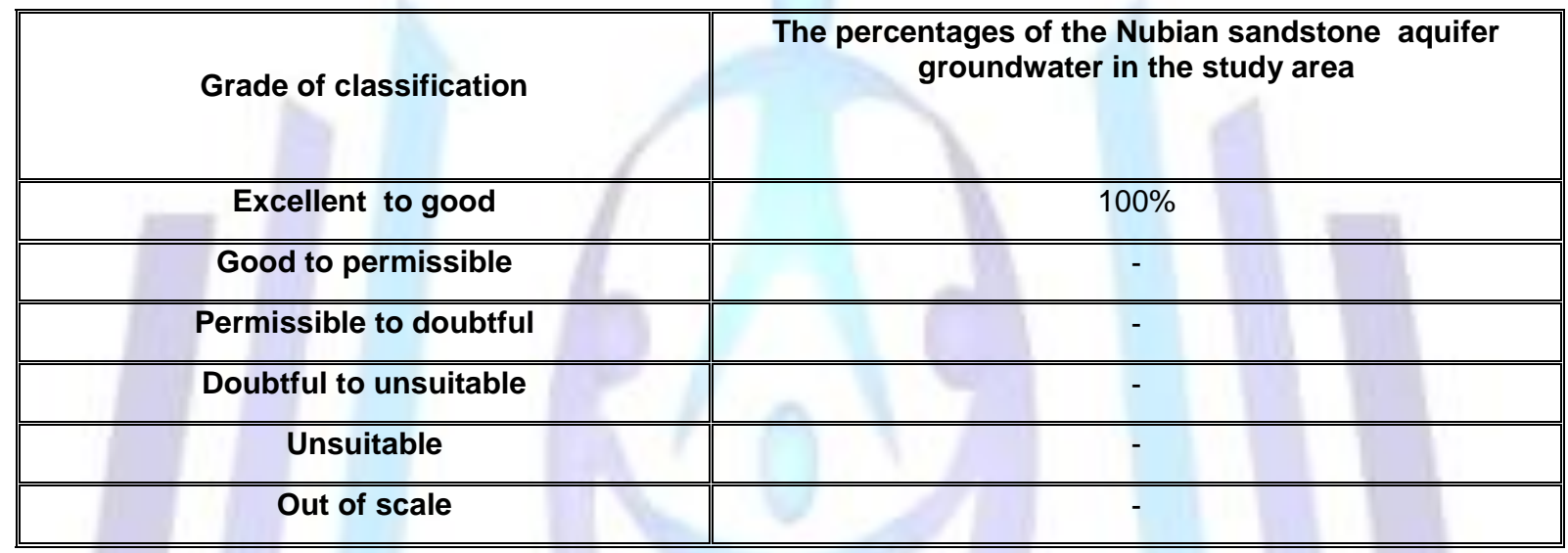

\subsection{2. b. Fractured dolomite and limestone aquifer}

From Table (14) and Fig. (13), it's obvious that, one sample (5\% of all samples of aquifer) is located in Doubtful to unsuitable class for irrigation, while $95 \%$ of samples are out of scale and unsuitable for irrigation.

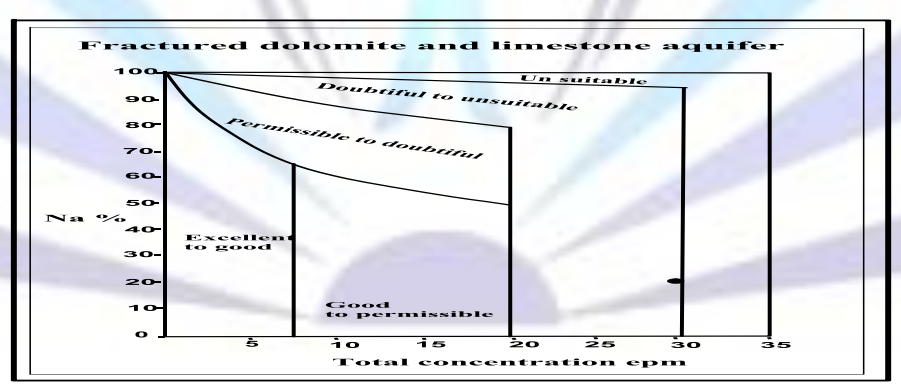

Fig. (13) Classification of the Fractured dolomite and limestone aquifer groundwater samples for irrigation purpose.

Table 14: Evaluation of water samples of the Fractured dolomite and limestone aquifer for irrigation according to Wilcox [15].

\begin{tabular}{|c||c||}
\hline Grade of classification & $\begin{array}{c}\text { The percentages of the Fractured dolomite and } \\
\text { limestone aquifer groundwater in the study area }\end{array}$ \\
\hline \hline Excellent to good & \\
\hline \hline Good to permissible & \\
\hline \hline Permissible to doubtful & - \\
\hline
\end{tabular}




\begin{tabular}{|c|c|}
\hline Doubtful to unsuitable & $5 \%$ \\
\hline Unsuitable & - \\
\hline Out of scale & $95 \%$ \\
\hline
\end{tabular}

\subsubsection{United States salinity laboratory staff [16].}

This classification is based on sodium adsorption ratio (SAR) and the specific conductance (expressed in $\mathrm{mmhos} / \mathrm{cm}$ at $25^{\circ} \mathrm{C}$ ), Table (15).

According to this classification, SAR is written as follows:

$$
\mathrm{SAR}=\mathrm{Na}+/ \sqrt{\frac{\mathrm{Ca} 2^{++} \mathrm{Mg} 2^{+}}{2}}
$$

Where, the concentrations of these cations are expressed in me/l. High values of SAR imply a hazard of sodium replacing adsorbed $\mathrm{Ca}^{2+}$ and $\mathrm{Mg}^{2+}$ and this replacement causes damaging of soil structure. The diagram of United States salinity laboratory staff is widely used for the evaluation of water for irrigation purposes and it consists of a plot of specific conductivity (in $\mu \mathrm{mhos} / \mathrm{cm}$ ) which is a function of the dissolved solids concentration against SAR. The waters are divided into four classes on basis of salinity $\left(\mathrm{C}_{1}, \mathrm{C}_{2}, \mathrm{C}_{3}\right.$ and $\left.\mathrm{C}_{4}\right)$ and four classes on the basis of SAR $\left(\mathrm{S}_{1}, \mathrm{~S}_{2}, \mathrm{~S}_{3}\right.$ and $\left.\mathrm{S}_{4}\right)$ giving a total of sixteen possible quality classes $\left(C_{1}-S_{1}, C_{1}-S_{2}, C_{1}-S_{3}, \ldots\right.$ etc. $)$, as inTable (15).

Table 15: The water quality classes according to the U. S. salinity laboratory Staff, [16].

\begin{tabular}{|c|c|c|c|}
\hline $\begin{array}{c}\text { Conductivit } \\
y\end{array}$ & Quality & Range & Usage \\
\hline C1 & $\begin{array}{l}\text { Low salinity } \\
\text { water }\end{array}$ & $100-250$ & $\begin{array}{l}\text { Can be used for irrigation of most crops in most soils } \\
\text { with little likelihood that soil salinity develops. }\end{array}$ \\
\hline $\mathbf{C 2}$ & $\begin{array}{c}\text { Medium } \\
\text { salinity water }\end{array}$ & $250-750$ & Can be used if a moderate amount of leaching occurs. \\
\hline C3 & $\begin{array}{l}\text { High salinity } \\
\text { water }\end{array}$ & $\begin{array}{l}750- \\
2250\end{array}$ & $\begin{array}{l}\text { Cannot be used on soil with restricted drainage even } \\
\text { with adequate drainage, special management for salinity } \\
\text { control may be required and plants with good salt } \\
\text { tolerant should be selected. }\end{array}$ \\
\hline C4 & $\begin{array}{l}\text { Very high } \\
\text { salinity }\end{array}$ & $>22500$ & $\begin{array}{l}\text { Is not suitable for irrigation under ordinary conditions, } \\
\text { but may be used occasionally under special conditions } \\
\text { as the soils must be permeable, and drainage must be } \\
\text { adequate, irrigation water must be applied in excess to } \\
\text { provide considerable leaching. }\end{array}$ \\
\hline SAR & Quality & Range & Usage \\
\hline$\overline{\mathrm{S1}}$ & $\begin{array}{l}\text { Low sodium } \\
\text { water }\end{array}$ & $0-10$ & $\begin{array}{l}\text { Can be used for irrigation of almost all soils with little } \\
\text { changes of the development of harmful levels of } \\
\text { exchangeable sodium. }\end{array}$ \\
\hline $\mathbf{S 2}$ & $\begin{array}{c}\text { Medium } \\
\text { sodium water }\end{array}$ & $10-18$ & $\begin{array}{l}\text { Will represents an appreciable sodium hazard in fine- } \\
\text { textured soils having high cation exchange capacity, } \\
\text { especially under low leaching conditions, unless gypsum } \\
\text { is present in the soil. }\end{array}$ \\
\hline S3 & $\begin{array}{l}\text { High sodium } \\
\text { water }\end{array}$ & $18-26$ & $\begin{array}{l}\text { May produce harmful levels of exchangeable sodium in } \\
\text { most soils and will require special soil management, } \\
\text { good drainage, high leaching and organic matter } \\
\text { condition. }\end{array}$ \\
\hline S4 & $\begin{array}{l}\text { Very high } \\
\text { sodium }\end{array}$ & $26-100$ & $\begin{array}{l}\text { Is generally unsatisfactory for irrigation purposes except } \\
\text { at low and perhaps land perhaps medium salinities. }\end{array}$ \\
\hline
\end{tabular}

Note: 1- The C2-S3 and C3-S3 water can be improved by adding gypsum to the soil. 


\section{2- The C2-S4 may be improved by the addition of gypsum to the water.}

By applying this classification on the groundwater samples in the area of study one can conclude the following:

\subsection{3. a. Nubian sandstone aquifer}

1) All the groundwater samples of the Nubian sandstone aquifer are good water for irrigation (C2-S1), can be used if a moderate amount of leaching occurs and used for irrigation of almost all soils with little changes of the development of harmful levels of exchangeable sodium Table (16) and Fig. (14).

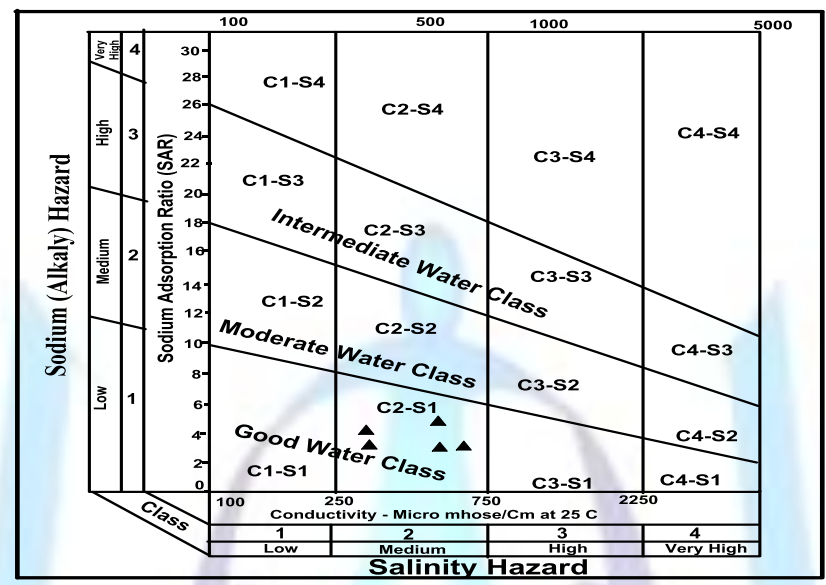

Fig.(14): Classification of groundwater of the Nubian sandstone aquifer for irrigation purposes. (According to the U.S. Salinity Laboratory Staff, [16].

Table (16): Evaluation of groundwater of the Nubian sandstone aquifer in the study area for irrigation according to Richards [16].

\begin{tabular}{|c||c||}
\hline Grade of classification & $\begin{array}{c}\text { The percentages of the Nubian } \\
\text { sandstone aquifer groundwater in the } \\
\text { study area }\end{array}$ \\
\hline \hline Good water class & $100 \%$ \\
\hline Moderate water class & - \\
\hline Intermediate water class & - \\
\hline Bad water class & - \\
\hline Out of scale & \\
\hline
\end{tabular}

\subsection{3. b. Fractured dolomite and limestone aquifer}

1) About $26 \%$ of the groundwater samples of the Fractured dolomite and limestone aquifer are Intermediate water for irrigation (C4-S3), is not suitable for irrigation under ordinary conditions, but may be used occasionally under special conditions as the soils must be permeable, and drainage must be adequate, irrigation water must be applied in excess to provide considerable leaching and may produce harmful levels of exchangeable sodium in most soils and will require special soil management, good drainage, high leaching and organic matter condition.., while $5 \%$ of the groundwater samples are considered as bad water for irrigation (C4-S4), is not suitable for irrigation under ordinary conditions, but may be used occasionally under special conditions as the soils must be permeable, and drainage must be adequate, irrigation water must be applied in excess to provide considerable leaching and is generally unsatisfactory for irrigation purposes except at low and perhaps land perhaps medium salinities. and $69 \%$ of the groundwater samples are out of scale, Table (17) and Fig. (15). 


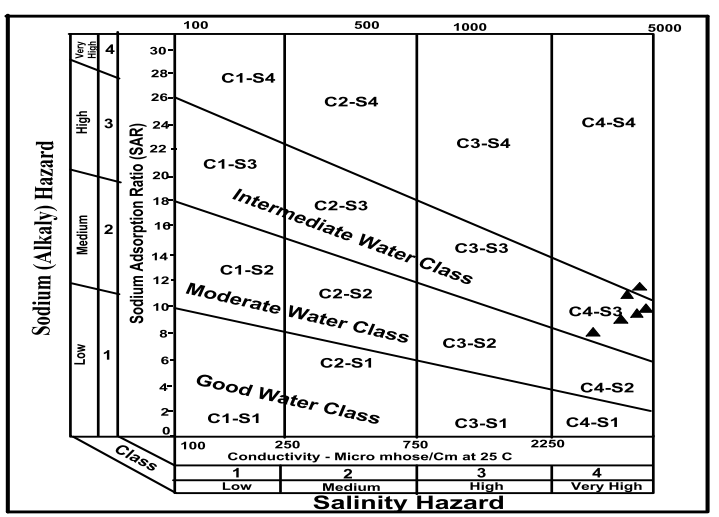

Fig.(15): Classification of groundwater of the Fractured dolomite and limestone aquifer for irrigation purposes. According to the U.S. Salinity Laboratory Staff, [16].

Table (17): Evaluation of groundwater of the Fractured dolomite and limestone aquifer in the study area for irrigation according to Richards, [16].

\begin{tabular}{|c||c|}
\hline Grade of classification & $\begin{array}{c}\text { The percentages of the Fractured } \\
\text { dolomite and limestone aquifer } \\
\text { groundwater in the study area }\end{array}$ \\
\hline \hline Good water class & - \\
\hline Moderate water class & $26 \%$ \\
\hline Intermediate water class & $5 \%$ \\
\hline Bad water class & $69 \%$ \\
\hline Out of scale & - \\
\hline
\end{tabular}

\subsubsection{Evaluation of Groundwater for Irrigation on Basis of the Crops and Their Salt Tolerance.}

By comparing the salinity data of the water samples in the study area Table (18) with the standards of crops and their salt tolerance (table 18), one can conclude the following:-

Table 18: Crops and their salt tolerance Richards, [16].

\begin{tabular}{|c|c|c|}
\hline $\begin{array}{c}\text { Sensitive crops } \\
\text { (Salinity }\end{array}$ & $\begin{array}{l}\text { Semi-tolerant crops } \\
\text { (4-10 mmhos /cm) }\end{array}$ & $\begin{array}{c}\text { Tolerant } \\
\text { crops }\end{array}$ \\
\hline$<4 \mathrm{mmhos} / \mathrm{cm}$ ) & & $(10-16 \mathrm{mmhos} / \mathrm{cm})$ \\
\hline Fruits: & & \\
\hline $\begin{array}{l}\text { Orchards, orange, apple, pear, } \\
\text { almond, beach, indian lemon, } \\
\text { apricot and mango. }\end{array}$ & $\begin{array}{l}\text { Figs, grapes, and } \\
\text { pomegranates. }\end{array}$ & $\begin{array}{l}\text { Olive, guavas and date } \\
\text { palm. }\end{array}$ \\
\hline $\begin{array}{l}\text { Vegetables: } \\
\text { Celery, radish and strawberry. }\end{array}$ & $\begin{array}{l}\text { Cauliflower, green } \\
\text { pepper, tomato, } \\
\text { potatoes, lettuces, } \\
\text { carrot, onion, peas, } \\
\text { squashes, cucumber } \\
\text { and watermelon. }\end{array}$ & Peanut, spinach. \\
\hline $\begin{array}{l}\text { Field crops: } \\
\text { Beans. }\end{array}$ & $\begin{array}{l}\text { Sunflower, peanut, } \\
\text { wheat, cesium, rice and } \\
\text { sorghum. }\end{array}$ & $\begin{array}{l}\text { Cotton, sugar beat } \\
\text { clover, barley and } \\
\text { cereals. }\end{array}$ \\
\hline
\end{tabular}




\subsection{4. a. Nubian sandstone aquifer}

1) From Table (19), it is clear that, all the groundwater samples of the Nubian sandstone aquifer are suitable for irrigation of all crops (sensitive, semi-tolerant and tolerant crops), since their salinities are $<4 \mathrm{mmhos} / \mathrm{cm}$.

Table 19: Evaluation of groundwater of the Nubian sandstone aquifer in the study area for irrigation according to Richards [16].

\begin{tabular}{||c||c||}
\hline $\begin{array}{c}\text { Salinity effects on } \\
\text { crop yield } \\
\text { (TDS in } \mathbf{g} / \text { ) }\end{array}$ & $\begin{array}{c}\text { The percentages of the Nubian sandstone } \\
\text { aquifer groundwater in the study area }\end{array}$ \\
\hline $\begin{array}{c}\text { Sensitive crops } \\
\text { salinity } \\
<4 \text { mmhos/cm }\end{array}$ & $100 \%$ \\
\hline $\begin{array}{c}\text { Semi-tolerant crops } \\
4-10 \text { mmhos/cm }\end{array}$ & - \\
\hline Tolerant crops \\
$10-16$ mmhos/cm
\end{tabular}

\subsection{4. b. Fractured dolomite and limestone aquifer}

1) From Table (20), it is clear that, $5 \%$ of the groundwater samples of the Fractured dolomite and limestone aquifer are suitable for irrigation of all crops (sensitive, semi-tolerant and tolerant crops), since their salinities are $<4 \mathrm{mmhos} / \mathrm{cm}$. while $69 \%$ of the samples are suitable for irrigation of the semi-tolerant and tolerant crops, since their salinities are 4-10 $\mathrm{mmhos} / \mathrm{cm}$. Also $26 \%$ of the total samples are suitable for irrigation of the tolerant crops, since their salinities are 10-16 $\mathrm{mmhos} / \mathrm{cm}$.

Table 20: Evaluation of groundwater of the Fractured dolomite and limestone aquifer in the study area for irrigation according to Richards [16].

\begin{tabular}{|c||c||}
\hline $\begin{array}{c}\text { Salinity effects on } \\
\text { crop yield } \\
\text { (TDS in } \mathbf{g} / \mathrm{l} \text { ) }\end{array}$ & $\begin{array}{c}\text { The percentages of the Fractured dolomite } \\
\text { and limestone aquifer groundwater in the } \\
\text { study area }\end{array}$ \\
\hline $\begin{array}{c}\text { Sensitive crops } \\
\text { salinity } \\
<4 \text { mmhos/cm }\end{array}$ & $5 \%$ \\
\hline $\begin{array}{c}\text { Semi-tolerant crops } \\
\text { 4-10mmhos/cm }\end{array}$ & $69 \%$ \\
\hline $\begin{array}{c}\text { Tolerant crops } \\
\text { 10-16mmhos/cm }\end{array}$ & \\
\hline Unsuitable & $26 \%$ \\
\hline 16 mmhos/cm & \\
\hline
\end{tabular}

\subsubsection{Doneen`s Classification [14].}

Regarding the Sodium content of irrigation water and its influence on soil permeability, the Doneen method (1961) is used. This method takes into consideration the main factors upon which the infiltration and the permeability rates of soils depend. These factors are the total concentration of dissolved ions (me/l), sodium content, bicarbonate content and soil type. The relationship between such factors has been defined by the term permeability index,

Permeability index $=\left\{\mathrm{Na}^{+}+\left(\mathrm{HCO}_{3}{ }^{-}\right)^{0.5}\right\} \times 100 /\left(\mathrm{Ca}^{2+}+\mathrm{Mg}^{2+}+\mathrm{Na}^{+}\right)$ 
Where all values are expressed in me/l. Doneen's classification consists of a plot of the permeability index against the total concentration to differentiate between the different classes of irrigation water according to soil permeability as follows, Table (21).

Table (21): Soil permeability types and their evaluation orders.

\begin{tabular}{|c||c||c||}
\hline Permeability of soil & Class & Evaluation for irrigation \\
\hline \hline \multirow{3}{*}{ Low } & I & First order \\
\cline { 2 - 3 } & I \& II & Second order \\
\cline { 2 - 3 } & III & Third order \\
\hline \hline \multirow{3}{*}{ Moderate } & I \& I & First order \\
\cline { 2 - 3 } & II & Second order \\
\cline { 2 - 3 } & III & Third order \\
\hline
\end{tabular}

Applying this classification on the groundwater of the study area reveals the abover, Table (20).

\subsection{5. a Nubian sandstone aquifer.}

About $(80 \%)$ of the groundwater samples of the Nubian sandstone aquifer can be classified as water of the third order (Classes III) of irrigation water, while (20\%) are lying out of the scale of the Doneen's diagram in case of soils of low permeability. Table (22) and Fig. (16).

Table (22): The evaluation of groundwater samples in the Nubian sandstone aquifer according to Doneen's method

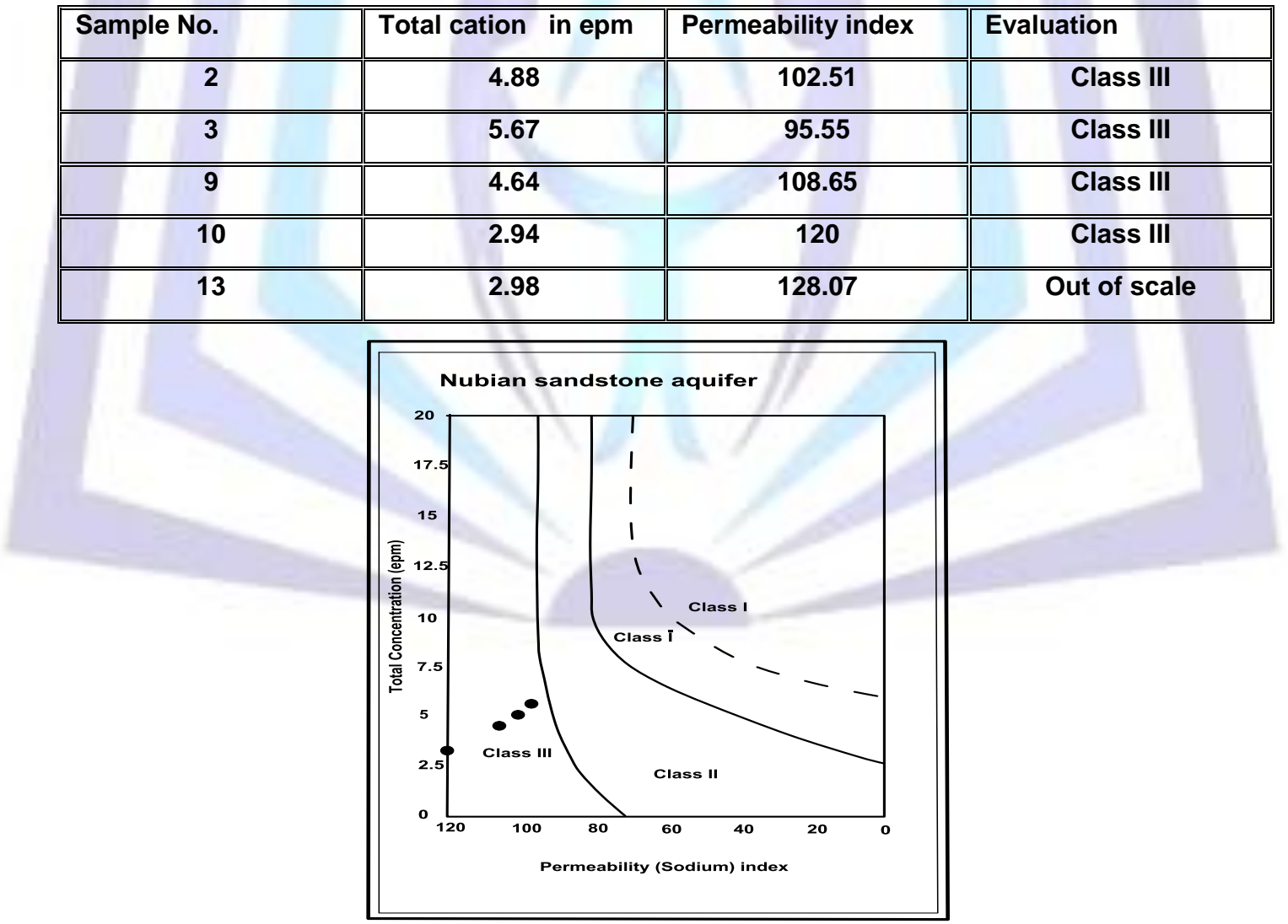

Fig. (16) Classification of groundwater samples in the Nubian

sandstone aquiferAccording to Doneen, [14].

\subsection{5. b. Fractured dolomite limestone aquifer.}

All the groundwater samples of the Fractured dolomite limestone aquifer are lying out of the Doneen's scale, in case of soils having high permeability, Table (23). 
Table (23): The evaluation of groundwater samples inthe Nubian sandstone aquifer according to Doneen's method

\begin{tabular}{|c|c|c|c|}
\hline Sample No & "Total cation in epm & Permeability index & Evaluation \\
\hline$\overline{c 1}$ & 38.22 & 75.83 & Out of scale \\
\hline 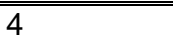 & 43.05 & 72.06 & Out of scale \\
\hline 6 & 56.44 & 73.84 & Out of scale \\
\hline$\overline{77}$ & 82.99 & 71.58 & Out of scale \\
\hline 8 & 51.80 & 71.60 & Out of scale \\
\hline 11 & 36.99 & 688.67 & Out of scale \\
\hline 12 & 39.18 & 688.31 & Out of scale \\
\hline 19 & 66.55 & 73.39 & Out of scale \\
\hline 20 & 45.83 & 71.33 & Out of scale \\
\hline 21 & 42.39 & 73.56 & Out of scale \\
\hline 22 & 30.00 & 68.16 & Out of scale \\
\hline 23 & 70.02 & 67.56 & Out of scale \\
\hline 24 & 42.59 & 67.45 & Out of scale \\
\hline 5 & 126.01 & 75.34 & Out of scale \\
\hline 14 & 108.34 & 67.91 & Out of scale \\
\hline 15 & 111.12 & 69.72 & Out of scale \\
\hline 16 & 111.18 & 69.21 & Out of scale \\
\hline 17 & 95.17 & 67.05 & Out of scale \\
\hline 18 & 104.68 & 73.49 & Out of scale \\
\hline
\end{tabular}

General conclusion: the majority of groundwater samples (83\%) in different aquifers of the study area located out of scale of the Doneen's diagram, i.e., most groundwaters in the different aquifers are unsuitable for irrigation. About $17 \%$ of groundwater samples of the study area are considered of the third order for irrigation in case of low permeability soil, according to Doneen's classification.

\subsubsection{Evaluation of Groundwater for Irrigation According To The Residual Sodium Carbonates. Eaton's Classification, [17].}

When the sum of carbonate and bicarbonate is in excess of calcium and magnesium, there is an almost complete precipitation of the formers (Eaton, 1950). This can cause an increase in the proportionate amount of sodium, and so, the effect on the soil is high sodium content. The term Residual Sodium Carbonate (RSC) is defined as follows:

$$
\mathrm{RSC}=\left(\mathrm{CO}_{3}{ }^{2-}+\mathrm{HCO}_{3}{ }^{-}\right)-\left(\mathrm{Ca}^{2+}+\mathrm{Mg}^{2+}\right) \text { all in epm/l. }
$$

The RSC is used to distinguish between the different water classes for irrigation purposes because the high concentration of bicarbonate leads to an increase in the $\mathrm{pH}$ value, which causes the dissolution of the organic matter. Moreover, the high concentration of bicarbonate ions in the irrigation water leads to its toxicity and affects the mineral nutrition of plants.

According to this parameter (i.e., RSC) reported by Eaton (1950) waters with RSC greater than 2.5 epm are considered unsuitable for irrigation, those with RSC in the range of 1.25-2.5 epm are marginal, and those with RSC less than 1.25 epm are safe.

Notably, the negative values of RSC for fractured dolomite limestone aquifer samples indicate no problem of carbonate and bicarbonate content in the irrigation water, i.e., the concentrations of both anions in groundwater samples of the study area are very low.

On the basis of the calculated RSC for groundwater samples of the different aquifers Table (24) the following could be deduced: 
Table 24: Evaluation of water samples in the different aquifers of the study area for irrigation according to RSC values, Eaton [17].

\begin{tabular}{|c||c||c|c|}
\hline $\begin{array}{c}\text { Values of } \\
\text { RSC }\end{array}$ & $\begin{array}{c}\text { Suitability of } \\
\text { groundwater } \\
\text { for irrigation }\end{array}$ & $\begin{array}{c}\text { Nubian } \\
\text { sandstone }\end{array}$ & $\begin{array}{c}\text { Fractured dolomite } \\
\text { limestone }\end{array}$ \\
\hline \hline$<1.25 \mathrm{epm}$ & Safe & $60 \%$ & $100 \%$ \\
\hline $1.25-2.5$ & Marginal & $40 \%$ & --- \\
\hline$>2.5$ & Unsuitable & -- & --- \\
\hline
\end{tabular}

\subsection{6. a. Nubian sandstone aquifer}

For Nubian sandstone aquifer samples of the groundwater about $(60 \%)$ of samples have values less than $1.25 \mathrm{epm}$, so these samples belongs to the safe water for irrigation. On other hand (40\%) of samples have values more than 1.25 epm so these samples belongs to the marginal water for irrigation.

\subsection{6. b. Fractured dolomite limestone aquifer}

All the groundwater samples of fractured dolomite limestone aquifer have RSC values less than 1.25epm(negative values), so such type of groundwater belongs to the possibly safe water for irrigation as it attains low residual sodium carbonate (RSC).

Generally, the majority of groundwater samples of the different aquifers in the study area are suitable for irrigation according to their RSC.

In conclusion, the evaluation of groundwater in the studied area for irrigation according to the above different classifications shows that the majority of groundwater samples in the studied area are unsuitable for irrigation while only few groundwater samples are suitable. However, this does not mean that the unsuitable waters can not entirely be used. In fact, the water suitability is associated with soil conditions and crop type. Therefore, at least some if not all groundwater samples in the study area can be used for irrigation but the expected yield productivity will not reach the optimum level.

From the geochemical study of the groundwater of different aquifers, it is clear that most groundwaters suffer from the problem of high soluble contents of heavy metals that make them unsuitable for the population drinking. So many trials to overcome such problems are essentially needed. This can possibly be done through synthesis of modified natural polymer resins and evaluate their applications in the treatment of groundwater types. In the current study, the polymer resins were synthesized from natural and cheap polymers to minimize the cost of a cubic meter of post-treatment water. In addition, such prepared resins have high efficiency for removal of soluble heavy metals resulting in an improvement of the groundwater quality.

\section{REFERENCES}

[1] Information Center, Statement Support Centre and decision-making, Matrouh Governorate, 2009 pp: 6,.

[2] Ministry of Irrigation. 2008.Report for Achievements of Management of Groundwater in Siwa, Report Siwa, Egypt, pp: $1-20$.

[3] Ministry of Irrigation. 2006. Report for Achievements of Drainage in Siwa, Report Siwa, Egypt, pp: 14.

[4] Gad. M. I. 2000. Western Desert, Egypt, Ph.D. Thesis. Faculty of Science Azhar University, pp: 22-28.

[5] Al-Kadi. 2003. M. Ain Shams University, M.Sc. Institute of Environmental Studies \& Research, pp: 151.

[6] Abo-Ragab and Samy. A. S. 2008. The 33rd International conference for statistics, Computer Science And It's Applications pp: 198-223.

[7] Samy. A. R.. 2010. Research Journal of Agriculture and Biological Sciences, 6(6): 791-805.

[8] American Society for testing and materials (ASTM). 2002. 11, pp.12.

[9] Higher Committee for Water "Egyptian standards for drinking water and domestic uses." .2007.Egypt. (In Arabic).

[10] Guidelines for drinking water quality. 2008. 2nd ed. Vol.2 Health criteria and other supporting information, World Health Organization.

[11] Durfor, C. N. and Becker, E. 1964. "Public water supplies of the 100 largest cities in the United States. 1962 ". U. S. Geological Survey Water Supply, paper 1812, 364pp.

[12] Mckee, J. E. and Wolf, H. W. 1963. "Water quality criteria ". California State Water Quality Board. Publ., 3A. U.S.A. 
[13] Doneen, L. D. 1959. "Evaluating the quality of irrigation water in Venture country ". State Department of Water Resources, U.S.A. Bull.75. Chapter II.

[14] Doneen, L. D. 1961. "The influence of crop and soil on percolating waters ". Proc. Groundwater recharge conference, U.S.A.

[15] Wilcox, L. V. 1948. "The quality of water for irrigation use." U.S. Dept. Agric., Tech. Bull., U.S.A., 962: 1-40.

[16] Richards, L. A. 1954. "Diagnosis and improvement of saline and alkaline soils." U.S. Dept. Agric. Handbook, No.60, U.S. Govt. Print. office, Washington, DC., U.S.A.

[17] Eaton, F.M. 1950. "Significance of carbonate in irrigation waters." Soil Sci., 69:127-128. 